\title{
Immune Response to the Carcinoembryonic Antigen in Patients Treated with an Anti-Idiotype Antibody Vaccine
}

\author{
Kenneth A. Foon, Mala Chakraborty, William J. John, Amanda Sherratt, Heinz Köhler, \\ and Malaya Bhattacharya-Chatterjee \\ Lucille Parker Markey Cancer Center and the Departments of Medicine and Microbiology and Immunology, University of Kentucky \\ Medical Center, Lexington, Kentucky 40536-0093
}

\begin{abstract}
We have generated an IgG1 murine monoclonal anti-idiotype antibody (Ab2) designated $3 \mathrm{H} 1$, which mimics a specific epitope on the carcinoembryonic antigen (CEA). Patients with CEA positive tumors are immunologically "tolerant" to CEA. We used $3 \mathrm{H} 1$ as a surrogate for CEA for vaccine therapy of 12 patients with advanced colorectal cancer. Each of the patients received a minimum of four intracutaneous injections of aluminum hydroxide precipitated 3H1 at either 1, 2, or $4 \mathrm{mg}$ dosage per injection. 9 of 12 patients demonstrated anti-anti-idiotypic $(\mathrm{Ab3})$ response to 3H1. All nine patients generated specific anti-CEA antibody demonstrated by reactivity with radiolabeled purified CEA; some cases were confirmed by immunoprecipitation of purified CEA. We also demonstrated Ab3 stained both autologous and allogeneic colonic tumors. 7 of 12 patients demonstrated idiotype specific $T$ cell proliferative responses and four also showed $T$ cell proliferation to CEA. Toxicity was limited to local reaction with mild fever and chills. All 12 patients eventually progressed after finishing 4-13 dosages. This is the first report demonstrating that a vaccine therapy is capable of breaking "immune tolerance" to CEA in patients with CEA positive tumors. Future studies will focus on treating patients with minimal residual disease. (J. Clin. Invest. 1995. 96:334-342.) Key words: carcinoembryonic antigen (CEA) • anti-idiotype antibody • vaccine therapy • colorectal cancer • tumor immunology
\end{abstract}

\section{Introduction}

Carcinoembryonic antigen (CEA $)^{1}$ is an $18-\mathrm{kD}$ glycoprotein tumor-associated antigen present on entodermally derived neoplasms of the gastrointestinal tract as well as other adenocarcinomas (1). CEA is also found in the digestive organs of the human fetus and, thus the name, CEA was derived. Circulating CEA can be detected in the great majority of patients with CEA positive tumors. Specific monoclonal antibodies have been

Address correspondence to Kenneth A. Foon, M.D., Lucille Parker Markey Cancer Center, 800 Rose Street, Room CC140, Lexington, KY 40536-0093. Phone: 606-257-4500; FAX: 606-323-2074.

Received for publication 22 September 1994 and accepted in revised form 14 February 1995.

1. Abbreviation used in this paper: CEA, carcinoembryonic antigen.

J. Clin. Invest.

(c) The American Society for Clinical Investigation, Inc. 0021-9738/95/07/0334/09 \$2.00

Volume 96, July $1995,334-342$ raised against CEA (2-4) and some have been radiolabeled for diagnostic and clinical studies (5). As with most tumorassociated antigens which are seen as self-antigens by the immune system, cancer patients are immunologically "tolerant" to CEA, likely related to its oncofetal origin. However, a limited number of reports from the 1970's suggested that some patients with CEA positive tumors may have minimal humoral and cellular immunity to CEA (6-10); these results are controversial.

The network hypothesis of Lindemann and Jerne $(11,12)$ offers an elegant approach to transform epitope structures into idiotypic determinants expressed on the surface of antibodies. According to the network concept, immunization with a given tumor-associated antigen will generate production of antibodies against this tumor-associated antigen, termed $A b 1$; this $A b 1$ is then used to generate a series of anti-idiotype antibodies against the Ab1, termed Ab2. Some of these Ab2 molecules can effectively mimic the three-dimensional structure of the tumor-associated antigen identified by the Abl. These particular anti-idiotypes called $\mathrm{Ab} 2 \beta$ fit into the paratopes of $\mathrm{Ab} 1$, and express the internal image of the tumor-associated antigen. The Ab2 $\beta$ can induce specific immune responses similar to those induced by the original tumor-associated antigen and can, therefore, be used as surrogate tumor-associated antigens. Immunization with $\mathrm{Ab} 2 \beta$ can lead to the generation of anti-anti-idiotype antibodies (Ab3) that recognize the corresponding original tumor-associated antigen identified by Abl. Because of this Ab1-like reactivity, the Ab3 is also called $A b 1$ ' to indicate that it might differ in its other idiotopes from $\mathrm{Ab1}$.

For several reasons, we consider CEA an excellent tumorassociated antigen for active immunotherapy with anti-idiotype antibody. First of all, CEA is typically present at high levels on the tumor cell surface. CEA is one of the most well-characterized antigens, its gene sequence is known and its three dimensional structures have been identified (13). CEA is a member of the immunoglobulin supergene family (14) located on chromosome 19 which is thought to be involved in cell-cell interactions. Since CEA is considered an adhesion molecule $(15,16)$, it might play an important role in the metastatic process by mediating attachment of tumor cells to normal cells. Thus, active immunotherapy targeted to CEA might be particularly beneficial in preventing metastasis.

Highly purified CEA is available from several sources and it can be used conveniently in serologic assays. Inasmuch as some of the epitopes on CEA are shared by normal tissues, immunization with intact CEA molecule might trigger potentially harmful autoimmune reactions. Whereas an $\mathrm{Ab} 2 \beta$ generated against an anti-CEA monoclonal antibody that recognizes a CEA-specific epitope, would be theoretically safer and more effective. Furthermore, Ab2 $\beta$ expressed in a different molecular environment have been shown to overcome the immunosuppression in the host by stimulating "silent clones," and/or allowing 
Table I. Patient Characteristics

\begin{tabular}{|c|c|c|c|c|c|c|c|c|c|}
\hline $\begin{array}{l}\text { Patient } \\
\text { No. }\end{array}$ & Age/sex & $\begin{array}{c}\text { Dosage } \\
(m g)\end{array}$ & $\begin{array}{l}\text { No. } \\
\text { doses }\end{array}$ & $\begin{array}{l}\text { Metastatic } \\
\text { disease }\end{array}$ & $\begin{array}{l}\text { Baseline } \\
\text { CEA level }\end{array}$ & $\begin{array}{l}\text { Humoral } \\
\text { response }\end{array}$ & Cellular & $\begin{array}{l}\text { Date off } \\
\text { study }\end{array}$ & Why off \\
\hline 1 & $72 / \mathrm{M}$ & 4 & 7 & lung & 160 & + & + & $3 / 10 / 94$ & progression \\
\hline 2 & $43 / F$ & 2 & 4 & liver & 110 & + & + & $12 / 9 / 93$ & progression \\
\hline 3 & $46 / F$ & 1 & 4 & lung, liver & 140 & + & + & $12 / 2 / 93$ & progression \\
\hline 4 & $61 / \mathrm{F}$ & 2 & 4 & lung, ileum & 60 & - & - & $12 / 11 / 93$ & progression \\
\hline 5 & $60 / \mathrm{M}$ & 1 & 7 & lung, liver & 3 & + & - & $5 / 2 / 94$ & progression \\
\hline 6 & $68 / \mathrm{M}$ & 4 & 8 & lung, liver & 81 & + & - & $5 / 16 / 94$ & progression \\
\hline 7 & $47 / M$ & 2 & 4 & liver & 15 & + & + & $3 / 17 / 94$ & progression \\
\hline 8 & $80 / \mathrm{F}$ & 1 & 4 & liver & 42 & - & - & $3 / 17 / 94$ & progression \\
\hline 9 & $51 / M$ & 4 & 4 & liver & 210 & + & + & 4/7/94 & progression \\
\hline 10 & $36 / \mathrm{M}$ & 1 & 8 & pelvis & 1 & - & - & $6 / 28 / 94$ & progression \\
\hline 11 & $70 / \mathrm{M}$ & 4 & 13 & lung & 58 & + & + & $2 / 20 / 95$ & progression \\
\hline 12 & $53 / \mathrm{F}$ & 2 & 5 & lung, liver & 35 & + & + & 6/9/94 & progression \\
\hline
\end{tabular}

T cell help to become active, making the overall immune response stronger which the nominal antigen (e.g., CEA) is unable to do $(17,18)$. Therefore, an appropriate anti-idiotype antibody would be an excellent candidate to induce anti-tumor immunity in CEA positive cancer patients.

A number of investigators have generated anti-idiotype antibodies in rats, mice, baboons and humans that mimic CEA (19-27). We have generated and characterized an anti-idiotype murine monoclonal antibody to a murine monoclonal antibody designated 8019 that identifies a specific epitope on CEA (28). This is a highly restricted CEA epitope that is not found on normal adult tissues and hematopoietic cells including granulocytes. The IgG1 anti-idiotype antibody generated to 8019 was shown to be an internal image by generating anti-anti-idiotypic (Ab3) responses in mice, rabbits (29), and monkeys (30) which recognized CEA. This anti-idiotype antibody was used to treat the patients reported in this clinical trial.

\section{Methods}

Selection of patients. All of the patients had CEA positive advanced colorectal carcinoma and failed standard therapies (Table I). Baseline studies included complete physical examination, chest radiography, computer axial tomography examination of the abdomen, serum CEA level, routine blood counts, and chemistries. All of the patients had been off prior therapy for at least four weeks and staging was repeated at the conclusion of therapy.

Treatment schedule. The patients were treated intracutaneously with either 1,2, or $4 \mathrm{mg}$ of aluminum hydroxide precipitated anti-idiotype antibody every other week for four injections. If the patients were stable at the end of the four injections, they were then continued with injections on a monthly basis and evaluated every 3 mo. Patients were removed from study if they demonstrated growth of their tumor.

Generation of anti-idiotype antibody for the clinical trial. Murine monoclonal antibody 8019 was used to immunize syngeneic BALB/c mice for the production of anti-idiotype antibody. Immunization of $\mathrm{BALB} / \mathrm{c}$ mice, hybridoma fusion and cloning, selection of anti-idiotype (Ab2), and production of ascites in bulk quantities in mice were done as previously described $(31,32)$. The $\mathrm{Ab} 2$ anti-idiotype $3 \mathrm{H} 1$ (IgG1) was purified from ascites by affinity chromatography on protein ACL Sepharose 4B column. The purity of the isolated immunoglobulin (> 95\%) was determined by sodium dodecyl sulfate polyacrylamide gel electrophoresis (SDS-PAGE) and high pressure liquid chromatography techniques. Sterility, pyrogenicity, polynucleotides, mycoplasma, and adventitious virus contamination and retrovirus removal validation tests were done in accordance with the United States Food and Drug Administration guidelines.

Preparation of final product. To augment the immunogenicity of anti-idiotype vaccine an adjuvant is typically required. Aluminum hydroxide has been approved by the United States Food and Drug Administration for use as an adjuvant in humans. For this clinical trial, antiidiotype $3 \mathrm{H} 1$ was precipitated with aluminum hydroxide. Briefly, $1 \mathrm{ml}$ of $2 \%$ Alu-Gel S (Serva Fine Biochem, Inc., Garden City, NY) was added to 5-mg aliquots of purified monoclonal anti-idiotype antibody. The volume was then adjusted to $10 \mathrm{ml}$ with D-PBS and the mixture incubated on a vortex for $1 \mathrm{~h}$ at room temperature. The mixture was then centrifuged at $2,000 \mathrm{rpm}$ at $25^{\circ} \mathrm{C}$ for $10 \mathrm{~min}$. The amount of antibody bound in the gel layer was determined by measuring spectrophotometrically the amount of unbound antibody in the supernatant. The Alu-Gel precipitated antibody was stored at $4^{\circ} \mathrm{C}$ until use. These procedures were performed aseptically in a laminar flow hood and the final product was sterile and clearly labeled as anti-idiotype $3 \mathrm{H} 1 \mathrm{Alu}-$ $\mathrm{Gel}$ and aliquoted into pyrogen-free, sterile glass vials.

The final product was tested for sterility, pyrogenicity and general safety in guinea pigs before use. An Investigational New Drug Application was approved through the United States Food and Drug Administration (BB-IND 5055).

Assays for humoral immunity. The development of humoral immunity induced by immunization with Alu-Gel-precipitated $\mathrm{Ab} 2$ was assessed by testing sera obtained from patients at different time points. The sera was initially tested for total human anti-murine-antibody responses including anti-iso/allo/and anti-anti-idiotype antibodies by sandwich radioimmunoassay (33). Briefly, microtiter plates were coated with $3 \mathrm{H} 1$ and incubated with different dilutions of patients' sera. After washing, the antigen-antibody reaction was tagged using ${ }^{125} \mathrm{I}$-labeled anti-Id $3 \mathrm{H} 1$ in a homogeneous sandwich radioimmunoassay. Since $3 \mathrm{H} 1$ is injected as intact IgG1, patients are expected to mount human anti-mouse antibody responses.

Specific $A b 3$ response to $A b 2$. Sera from immunized patients with positive human anti-mouse antibody responses were tested for the presence of anti-anti-idiotypic antibodies. Sera were pre-incubated with normal murine immunoglobulin to block human antibodies against isotypic and allotypic determinants and then checked for the presence of antianti-idiotype $(\mathrm{Ab} 3)$ by reaction with the immunizing anti-idiotype (3H1) coated onto microtiter plates. Unrelated Ab2 was used as control. After washing, the antigen-antibody reaction was tagged using ${ }^{125} \mathrm{I}$ labeled anti-idiotype reagent in a homogeneous sandwich radioimmunoassay as above. Pretreatment, non-immune sera and sera from normal donors were used as controls in these assays.

Inhibition of the binding between $A b 1$ and $A b 2$ by patients' $A b 3$ 
antibodies by radioimmunoassay. Pre-immune and hyperimmune patient sera samples were treated with unrelated murine immunoglobulins to remove anti-idiotypic and allotypic reactivities. Serial dilution's of sera were then tested for inhibition in the Ab1-Ab2 binding assay. All assays were performed in triplicate. For direct binding inhibition assay between $\mathrm{Ab} 1$ and $\mathrm{Ab} 2$, purified $\mathrm{Ab} 23 \mathrm{H} 1$ was used to coat plates ( $500 \mathrm{ng} /$ well) and the binding of radiolabeled 8019 (Ab1) to Ab2 was tested for inhibition in the presence of different patients' hyperimmune Ab3 sera and Ab1. This demonstrated whether Ab3 in patients' sera shared idiotopes with 8019 (Ab1). Also, this inhibition assay between Ab1-Ab2 binding by $\mathrm{Ab} 3$ sera indicated whether $\mathrm{Ab} 3$ is a true anti-anti-idiotype.

Detection of anti-CEA antibodies in patients immunized with Ab2 $3 \mathrm{H1}$. This assay was conducted to determine whether some of the Ab3 induced in patients by monoclonal murine $\mathrm{Ab} 2$ were of the Ab1 type and will bind to CEA. Purified CEA was radioiodinated with $\mathrm{I}^{125}$ by the Chloramine T method. Radiolabeled CEA $\left(1 \times 10^{6} \mathrm{cpm}\right)$ was reacted with $0.5 \mathrm{ml}$ of patient's serum pre-adsorbed on protein G-Sepharose beads. After reactions, the beads were washed and counted in a gamma-ray spectrophotometer. Pre-immune sera, phosphate-buffered saline-bovine serum albumin as well as Ab3 sera obtained from a patient treated with an unrelated murine monoclonal antibody for $\mathrm{T}$ cell lymphoma were used as controls in these assays.

Purified CEA. Purified CEA was obtained commercially from Rougier Biotech, Montreal, Canada (cat. No. 70015). CEA was isolated from human liver metastasis of colonic tumors by perchloric acid extraction and purified twice by ion-exchange chromatography followed by gel filtration and several steps of HPLC chromatography. The CEA is $100 \%$ pure, produced a single band at $18 \mathrm{kD}$ by high power liquid chromatography and SDS-PAGE and was immunoprecipitated as a single band by horse as well as rabbit anti-CEA antibody. The CEA preparation was resolved into two closely migrating bands at 18 and $20 \mathrm{kD}$ by Western blot analysis using murine monoclonal anti-CEA antibody. We rechecked the material by Western blot analysis using monoclonal antibody 8019.

Flow cytometry analysis with Abl and patient's Ab3. CEA-positive colorectal cancer derived LS174-T cells $\left(1 \times 10^{6}\right.$ per well $)$ and CEAnegative B cell lymphoma, Raji cells $\left(1 \times 10^{6}\right.$ per well $)$ were reacted with $\mathrm{Ab1}(8019)$ and patient's immune sera $(\mathrm{Ab} 3)$ at 1:100 dilution at $4^{\circ} \mathrm{C}$ for $60 \mathrm{~min}$. After washing, the cells were incubated with either goat anti-human or goat anti-mouse $\mathrm{F}\left(\mathrm{ab}^{\prime}\right)_{2}$ IgG-FITC labeled antibody (Tago) for $30 \mathrm{~min}$ at $4^{\circ} \mathrm{C}$. They were then washed twice, fixed in $2 \%$ paraformaldehyde and analyzed by flow cytometry (FACS ${ }^{\circledR}$ Star, Becton Dickinson).

Purification of anti-anti-idiotypic antibody ( $\mathrm{Ab} 3$ ) from hyperimmunized patients' sera. $50 \mathrm{ml}$ of hyperimmune serum were passed over an immunoadsorbent column consisting of immunizing anti-idiotype immunoglobulin (3H1) coupled to Sepharose 4B. Anti-anti-idiotypic antibodies ( $\mathrm{Ab} 3$ ) bound to the column were eluted with $0.1 \mathrm{M}$ glycinehydrochloric acid buffer ( $\mathrm{pH} 2.4$ ). The eluted antibody was neutralized with $3 \mathrm{M}$ Tris, dialyzed against $\mathrm{PBS}, \mathrm{pH} 7.2$, and then passed over an immunoadsorbent column consisting of allotype matched normal mouse immunoglobulin coupled to Sepharose 4B to remove anti-isotypic and anti-allotypic reactivities. Antibody that passed through was concentrated and used as purified Ab3. The isotype of Ab3 was determined by ELISA using human anti-isotype specific reagents (Tago).

Epitope analysis of $A b 3$ by radioimmunoassay inhibition assay. To determine whether Ab3 sera compete with Ab1 for binding to human colon carcinoma cells, the binding of radioiodinated 8019 to confluent monolayers of LS174T cells was tested for inhibition in the presence purified Ab3 and Ab1 preparations.

Immunoprecipitation of $C E A$ by $A b 1$ and $A b 3$. Purified CEA was labeled with ${ }^{125} \mathrm{I}$ by The Chloramine T-method and reacted with purified $\mathrm{Ab} 3(10 \mu \mathrm{g})$ or $\mathrm{Ab} 1(10 \mu \mathrm{g})$ or unrelated control $\mathrm{Ab} 3$ from lymphoma patient $(10 \mu \mathrm{g})$ or PBS-BSA control, previously adsorbed on to protein G-Sepharose beads. After washings, The antigen-antibody coated beads were analyzed by SDS-PAGE according to the method of Laemmli (34) and radioautographed.

Immunoperoxidase staining of tumor sections with Abl and Ab3.
The reactivities of monoclonal $\mathrm{Ab} 1$ and purified $\mathrm{Ab} 3$ at $10 \mu \mathrm{g} / \mathrm{ml}$ solution were compared on surgical specimens of colonic adenocarcinomas by a very sensitive staining method (biotin-Streptavidin reagents; Vector, Burlingame, CA) as described in detail elsewhere (27). All sections were counterstained with Meyer's hematoxylin. Pertinent specificity tests were performed, including block of the endogenous peroxidase, omission of the first layer, or substitution of nonimmune homologous serum for the specific antiserum and P3-653 myeloma culture supernatant as the control.

Assay for $T$ cell proliferative response. Peripheral blood mononuclear cells were isolated by standard Ficoll-Hypaque density gradient centrifugation method and $5 \times 10^{5}$ cells per well were incubated with different concentrations of 3H1-Alu-Gel and control 4DC6-Alu-Gel ( 10 $\mathrm{ng}$ to $2 \mu \mathrm{g}$ ) in RPMI medium with 5\% heat-inactivated fetal calf serum and penicillin and streptomycin. The nonspecific mitogen phytohemagglutinin-P was used as a positive control at 2 and $1 \mu \mathrm{g}$ per well. After the cells were incubated for $5 \mathrm{~d}$ at $37^{\circ} \mathrm{C}$ in an atmosphere containing $5 \%$ carbon dioxide, they were pulsed with $\left[{ }^{3} \mathrm{H}\right]$ thymidine $(1 \mu \mathrm{Ci}$ per well) for $20 \mathrm{~h}$. Data were expressed as mean counts (triplicate wells) per minute of $\left[{ }^{3} \mathrm{H}\right.$ ] thymidine incorporation. The Standard Deviation of the data was $<10 \%$ for each determination.

Peripheral blood mononuclear cells isolated from some selected patients were also incubated with different concentrations of purified CEA (10-250 ng) as per protocol above.

Assay for circulating CEA in serum. CEA was quantified in heat-

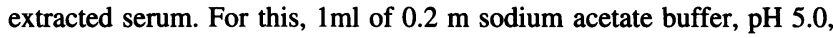
was added to $0.5 \mathrm{ml}$ of serum, vortex-mixed, incubated for $15 \mathrm{~min}$ at $90^{\circ} \mathrm{C}$, and centrifuged $(1,200 \mathrm{~g}, 10 \mathrm{~min})$. The supernatants were assayed the same day or stored frozen at $-20^{\circ} \mathrm{C}$ until assay. $100 \mathrm{ml}$ of supernatant was then assayed by the enzyme immunoassay for CEA as described (35).

\section{Results}

Humoral responses to anti-idiotype. The development of humoral immunity induced by immunization with Alu-Gel-precipitated $\mathrm{Ab} 2,3 \mathrm{H} 1$ was assessed by testing sera obtained from patients before therapy and after each treatment with the vaccine. Hyperimmune sera (after the fourth injection of 3H1) from nine of twelve patients showed significant levels of total human anti-mouse antibody responses including anti-iso/allo/ and anti-anti-idiotypic antibodies against immunizing $\mathrm{Ab} 2$, $3 \mathrm{H} 1$, as determined by homogeneous sandwich radioimmunoassay (data not shown). Next the sera from these immunized patients were checked for their ability to inhibit the binding of ${ }^{125}$ I-labeled $\mathrm{Ab} 1,8019$ to $\mathrm{Ab} 23 \mathrm{H} 1$ on the plate by radioimmunoassay or vice versa (inhibition of radiolabeled $\mathrm{Ab} 2$ binding to $\mathrm{Abl}$ on the plate). These reactions were done in the presence of excess normal murine immunoglobulin to block human antibodies against isotypic and allotypic determinants. Fig. 1 demonstrates representative data from the first five patients. Sera from patients $1,2,3$, and 5 , at $1 / 10$ dilution, inhibited binding of iodinated 8019 to $3 \mathrm{H} 1$ by $62-\sim 100 \%$ and inhibition of binding decreased with increasing dilution of the sera. Sera from patient 4 showed minimal nonspecific inhibition at all dilutions used and pre-immune sera showed no inhibition. Although steric hindrance by $\mathrm{Ab} 3$ binding can not be excluded in these assays, the results suggest the presence of true anti-antiidiotypic antibodies that share idiotypes with Ab1. Again, nine out of twelve patients were positive for $\mathrm{Ab} 3$ responses by this assay.

Induction of anti-CEA antibodies by anti-idiotype $3 \mathrm{HI}$. Next, we investigated whether $3 \mathrm{H} 1$ could induce an anti-CEA antibody response in immunized patients. For this, the crude 


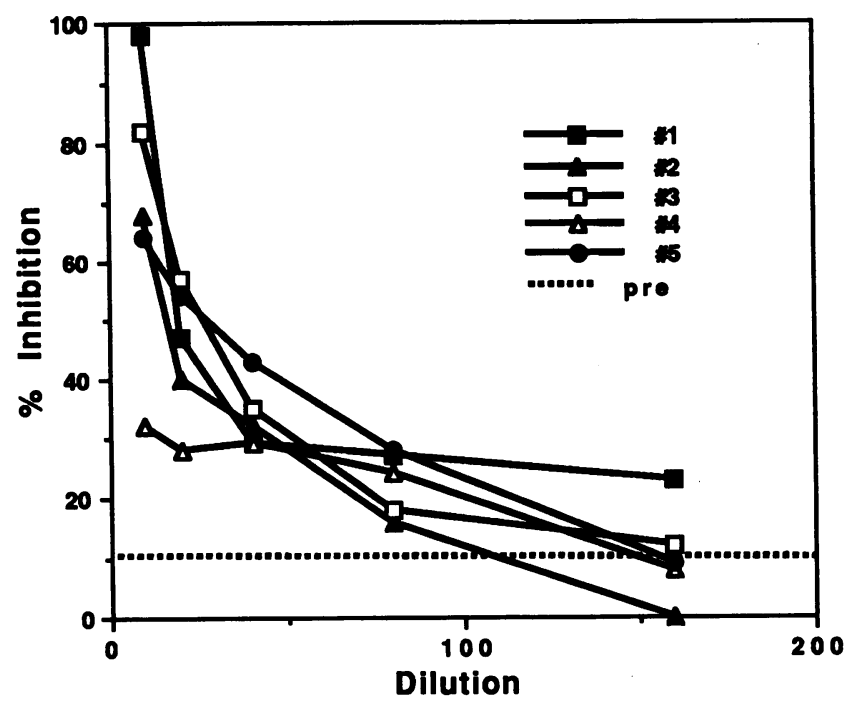

Figure 1. Inhibition of $\mathrm{Ab1}(8019)$ binding to $\mathrm{Ab} 2$ (3H1) on the plate by patients' Ab3 sera by radioimmunoassay. Purified $3 \mathrm{H} 1$ was used to coat the plate $(500 \mathrm{ng} /$ well) and the binding of radiolabeled 8019 $(\sim 90,000 \mathrm{cpm})$ to $3 \mathrm{H} 1$ was tested for inhibition in the presence of various dilutions of $\mathrm{Ab} 3$ sera obtained from patients after the fourth immunization.

sera obtained from patients after the fourth treatment were tested for the presence of antibody binding to radiolabeled purified CEA. We routinely used post fourth immunization because this was the number of injections all 12 patients received. For patients who received more than four injections, immune responses remained comparable or continued to increase in titer. A pure preparation of CEA was used to reduce the risk of obtaining false positive results due to nonspecific binding. As shown in Fig. 2, immunization with $3 \mathrm{H} 1$ induced antibodies that bound to radiolabeled CEA. Nine of twelve patients developed anti-CEA antibodies measurable by this assay. Patients 4 , 8 , and 10 were anergic for human anti-mouse antibody response and did not produce antibodies against CEA, while patients $1,2,3,5$, and 12 showed high binding, and patients 6 , 7,9 , and 11 showed binding greater than the background count obtained with PBS-BSA (Sample 13) or pre-immune sera (data not shown). Sample 14 was the Ab1 8019 antibody used as a positive anti-CEA (8019) control.

Immune flow cytometry analysis with $\mathrm{Ab1}$ and patient's $\mathrm{Ab3}$. To determine the reactivity with cell-surface CEA, cultured CEA positive human colon cancer LS174T cells were tested by immune flow cytometry. As shown in Fig. 3, crude sera from a representative $3 \mathrm{H} 1$-immunized patient bound to $\mathrm{LS} 174 \mathrm{~T}$ cells $(A)$ similar to the binding pattern obtained with $8019(B)$ and did not bind to human $B$ cell lymphoma cells which do not express CEA (Fig. $3 \mathrm{C}$ ). Similar results were found with all of the positive patients.

Competition of Abl and patient's Ab3 for binding to LS174$T$ cells. If $\mathrm{Ab} 3$ has a similar binding site as $\mathrm{Ab} 1$, it should compete with Ab1 for binding to CEA on LS174-T cells. A fixed amount of radiolabeled 8019 was co-incubated with different concentrations of patientUs purified $\mathrm{Ab3}$ or $\mathrm{Ab} 1$ preparations and LS174-T cells (Fig. 4).

Purified 8019-IgG1 (Ab1) inhibited binding by $80 \%$ at 0.75 $\mu \mathrm{g}$ whereas patient's purified $\mathrm{Ab} 3$ (from patient 1 ) produced $60 \%$ inhibition at the same concentration. Overall, the inhibition

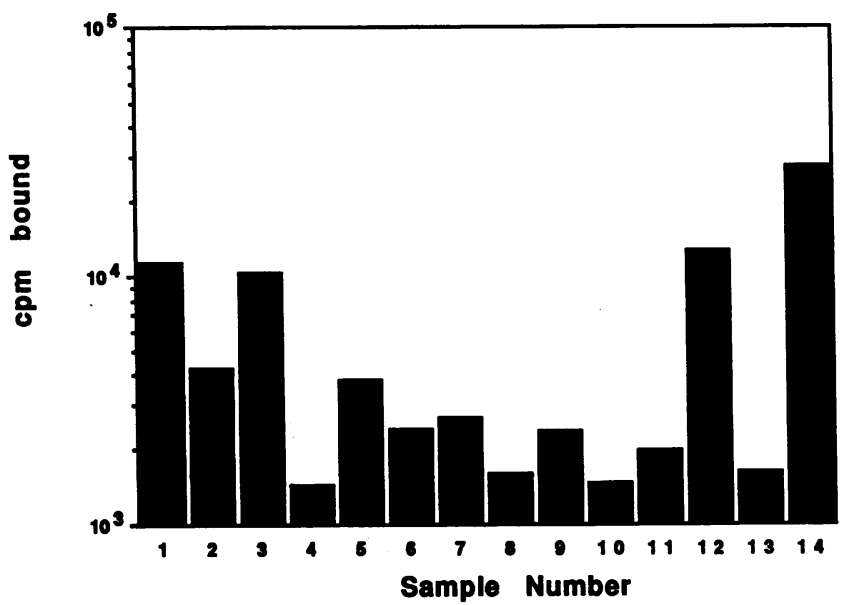

Figure 2. Reactivity of patients' Ab3 with purified radiolabeled CEA. Patients' sera $(0.5 \mathrm{ml})$ obtained after the fourth immunization was adsorbed on to protein $\mathrm{G}-$ Sepharose $4 \mathrm{~B}$ beads and reacted with $(\sim 1$ $\times 10^{6} \mathrm{cpm}$ ) radiolabeled CEA. After the reaction, the mixture was centrifuged, the precipitate was washed and counted in a gammacounter. Each sample was performed in duplicate and the mean of the cpm bound is shown. Samples 1 through 12 were obtained from patients 1 through 12. Sample 13 was PBS-BSA control and 15 was Ab1 8019, used at $10 \mu \mathrm{g}$ concentration. No reactivity (cpm bound) greater than PBS-BSA was observed with pre-immune sera from these patients.

curves obtained with $\mathrm{Ab} 1$ and $\mathrm{Ab} 3$ were very similar at different dilutions. This indicated that the patient's Ab3 bound to the same antigenic epitope as $\mathrm{Abl}$ and therefore contained antibody molecules with $\mathrm{Ab1}$ ' properties.

Immunoprecipitation of $C E A$ by $A b 1$ and $A b 3$. It had been previously shown that Ab1 8019 specifically immunoprecipitated the $18 \mathrm{kD}$ CEA by SDS-PAGE analysis (29). To confirm that the $\mathrm{Ab} 3$ induced by $3 \mathrm{H} 1$ was specific for the CEA molecule, the iodinated purified CEA preparation was immunoprecipitated by purified $\mathrm{Ab} 3$ preparations obtained from two patients as well as Ab1 and analyzed by SDS-PAGE. The results in Fig. 5 indicate that both patient's Ab3 (lanes 2 and 3 ) precipitated the same $18 \mathrm{kD}$ CEA band as that of murine Ab1 8019 (lane 1). There was no cross-reactivity (lane 4 ) when the iodinated CEA was reacted with purified $\mathrm{Ab} 3$ obtained from a patient treated with an unrelated Ab2 (4DC6). When iodinated CEA, pretreated with either of the two positive patients' $\mathrm{Ab} 3$ preparations, was reacted with 8019 , there was no significant immunoprecipitation suggesting that the iodinated preparation was depleted of CEA (data not shown).

Immunoreactivity of $A b 1$ and patients' $A b 3$ on colonic tumor sections and normal tissues. We compared the reactivities of $\mathrm{Ab1}(8019)$ with that of patients' purified Ab3 by a sensitive immunoperoxidase assay on autologous and allogeneic colon tumor specimens surgically removed from patients. The pattern of reactivity of patient $\mathrm{Ab} 3$ on autologous malignant colon tissues was identical to that obtained with allogeneic tumor specimens (Fig. 6, $A$ and $B$, respectively). Abl 8019 showed identical staining patterns (Fig. $6 C$ ), whereas there was no reactivity with control $\mathrm{Ab} 3$ obtained from a patient treated with an unrelated $\mathrm{Ab2}$ (4DC6) (Fig. $6 \mathrm{D}$ ). Reactions with $\mathrm{Ab} 1$ or purified Ab3 (Fig. 6, $A-C$ ) resulted in the staining of both tumor cells as well as secreted mucinous materials. The staining was apical in gland-like structures and granular (cytoplasmic) in less dif- 

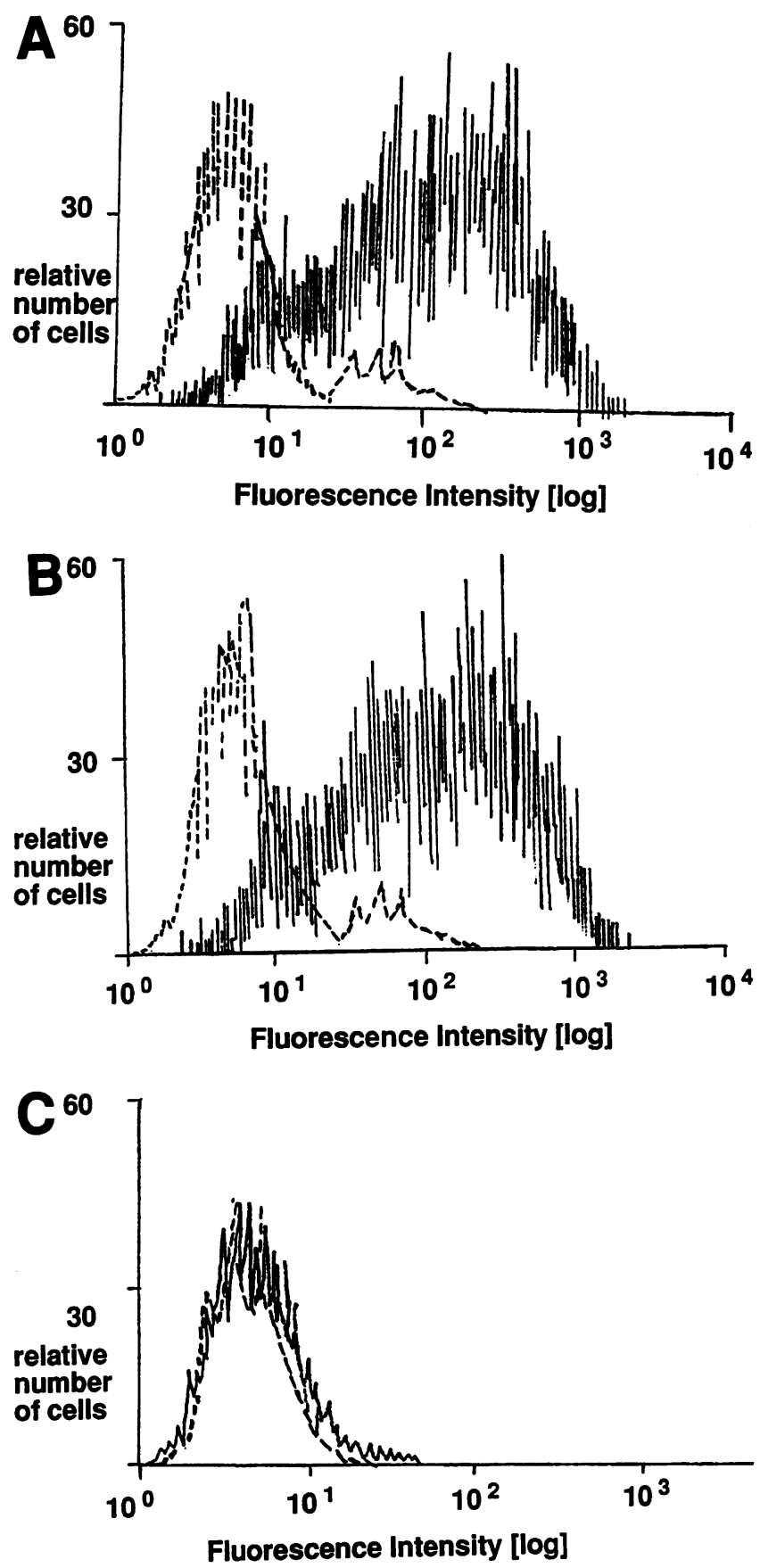

Figure 3. Flow microfluorimetry analysis of the CEA positive colon cancer cell line, LS174-T, with patients' Ab3 sera. Tumor cells were reacted with $A b 3$ sera (1/100 dilution) from patients immunized with $\mathrm{Ab} 2,3 \mathrm{H1}(A)$ and murine Ab1 $8019(B)$. The reaction was developed with goat anti-human or anti-mouse $\mathrm{F}\left(\mathrm{ab} \mathrm{b}^{\prime}\right) 2$ IgG-FITC labeled antibody respectively. Preimmune patient's sera were used as control. In $C$, human B cell lymphoma cells, Raji, that do not express CEA were reacted with patient's Ab3 and preimmune sera. Symbols used: (-----) preimmune serum in $A-C$; (-) $\mathrm{Ab3}$ serum in $A$ and $C$; and (-) Ab1 8019 in $B$.

ferentiated areas. There was no reactivity of $\mathrm{Abl}$ and purified Ab3 on normal tissues from colon (Fig. 6, $E$ and $F$ ), cecum, duodenum, stomach striated muscle or smooth muscle.

Cellular immune responses to anti-idiotype. Cellular immune responses were measured by the proliferation of periph-

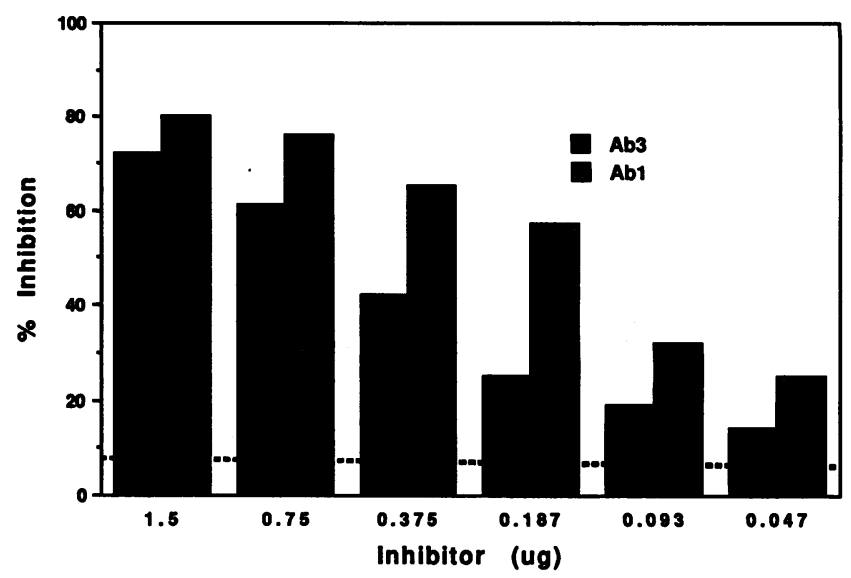

Figure 4. Inhibition of Ab1 binding to LS174-T cells by patient's Ab3. Confluent monolayers of LS174-T cells in microtiter plates were reacted with different concentrations of $\mathrm{Ab} 3$ and $\mathrm{Abl}$ and a fixed amount of ${ }^{125} \mathrm{I}-8019(\sim 90,000 \mathrm{cpm})$. Percent inhibition was calculated as described in Methods. The cpm obtained with excess Ab1 (8019) was considered as background.

eral blood mononuclear cells incubated with Alu-Gel precipitated anti-idiotype antibody $3 \mathrm{H} 1$ and Alu-Gel precipitated isotype matched control anti-idiotype antibody 4DC6. Positive proliferative responses were seen in seven of twelve patients. All seven of these patients developed an Ab3 antibody response (Table I). Representative data from two patients (1 and 12) are shown in Fig. 7, $A$ and $B$. Pre-immune cells had no proliferative response to the anti-idiotype antibody while hyperimmune cells had a significant response. Four of the seven responding patients (two treated with a 2-mg dose and two with a 4-mg dose) also showed $\mathrm{T}$ cell proliferation in the presence of purified CEA suggesting antigen specific $\mathrm{T}$ cell response. There was also a response to the isotype matched 4DC6 Alu-Gel-precipitated anti-idiotype antibody; this response was significantly less than that of the $3 \mathrm{H} 1$ response, likely representing a response to the non-idiotype components of the murine immunoglobulin molecule. The difference in the response to $3 \mathrm{H} 1-\mathrm{Alu}-\mathrm{Gel}$ compared with control 4DC6-Alu-Gel was significant $(P<0.003)$ as was the response to CEA compared to BSA $(P<0.005)$. There was no response to Alu-Gel itself (data not shown). Flow cytometric analysis of the cultures demonstrated that $>90 \%$ of the proliferating cells were CD4 positive $\mathrm{T}$ lymphocytes. The three patients

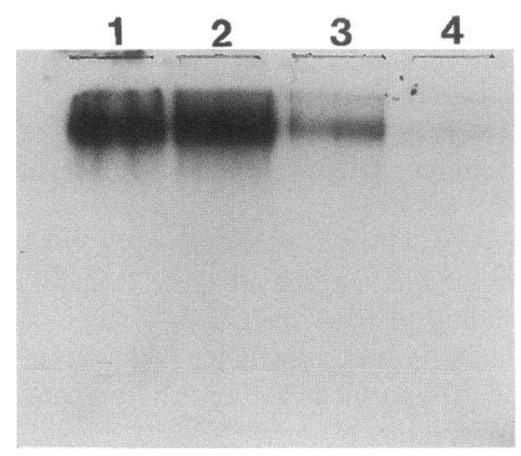

Figure 5. SDS-PAGE pattern of ${ }^{125}$ I-labeled CEA after immunoprecipitation with 8019 (lane 1), Ab3, patient 1 (lane 2), Ab3, patient 2 (lane 3), and Ab3, patient treated with unrelated $\mathrm{Ab2}$ (lane 4). Amount of antibodies used per gel was $10 \mu \mathrm{g}$. Radiolabeled CEA was incubated with dif-

ferent $\mathrm{Ab} 1$ and $\mathrm{Ab} 3$ preparations, and the precipitated molecules were analyzed by SDS-PAGE and autoradiography. The film was exposed for $3 \mathrm{~d}$. 

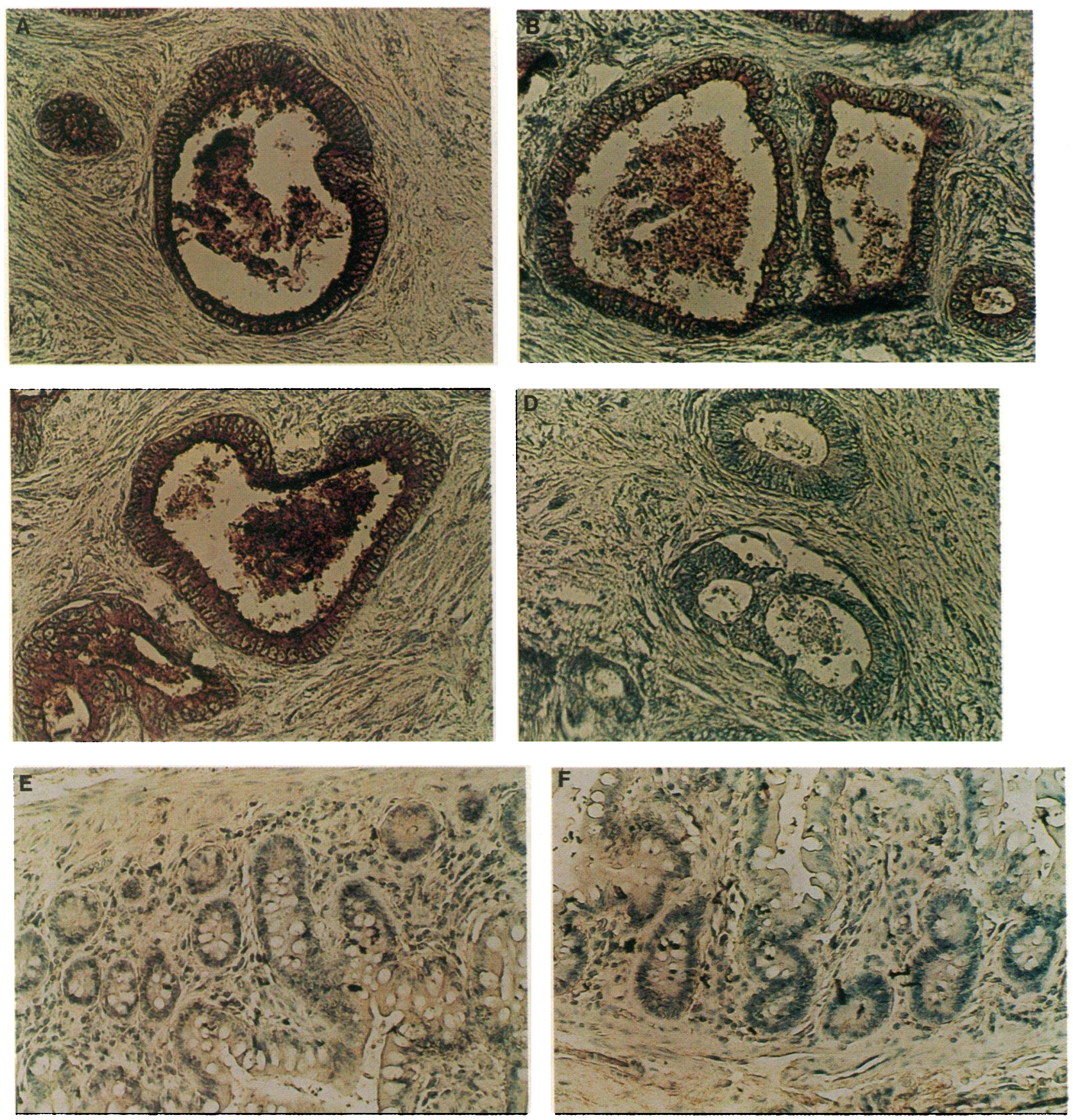

Figure 6. Immunoperoxidase staining of autologous and allogeneic colonic adenocarcinomas and normal colon by Ab1 and patients' Ab3. Serial sections were stained with; $(A)$ patients' $\mathrm{Ab} 3(50 \mu \mathrm{g} / \mathrm{ml})$ on autologous tumor; $(B)$ patients' Ab3 $(50 \mu \mathrm{g} / \mathrm{ml})$ on allogeneic tumor; $(C) 8019 \mathrm{IgG}{ }_{1}$ $(50 \mu \mathrm{g} / \mathrm{ml}) ;(D) \mathrm{Ab} 3(50 \mu \mathrm{g} / \mathrm{ml})$ from patient treated with an unrelated anti-idiotype antibody (4DC6) on tumor sections as in A; $(E) 8019$ IgG1 $(50 \mu \mathrm{g} / \mathrm{ml})$ on normal colon; $(F)$ patients' Ab3 $(50 \mu \mathrm{g} / \mathrm{ml})$ on normal colon.

who were anergic for human anti-mouse antibody response also did not demonstrate any $\mathrm{T}$ cell proliferative response. Of the five nonresponders, three were treated with $1 \mathrm{mg}$, one with 2 $\mathrm{mg}$ and one with $4 \mathrm{mg}$ dosage of $3 \mathrm{H} 1-$ Alu-Gel.

Toxicity and clinical response. Toxicity was minimal with only local reactions at the injection site with mild erythema and induration and mild fever and chills relieved by acetaminophen. The anti-idiotypic treatment did not have any deleterious effect on hematopoietic cells, renal, or hepatic function.

Patients were monitored very closely for disease activity.
All 12 patients eventually developed progressive disease (Table I).

Serial monitoring of circulating CEA. Indirect measurement of extent of disease (CEA level) was recorded prior to immunization and determined after each immunization and then once monthly following completion of the immunization schedule. For this, patients' sera was heat-inactivated to precipitate the immunoglobulins which would interfere with the CEA monitoring assays involving murine monoclonal Ab1. CEA is heat stable, and was measured in the clear centrifuged supernatant by 

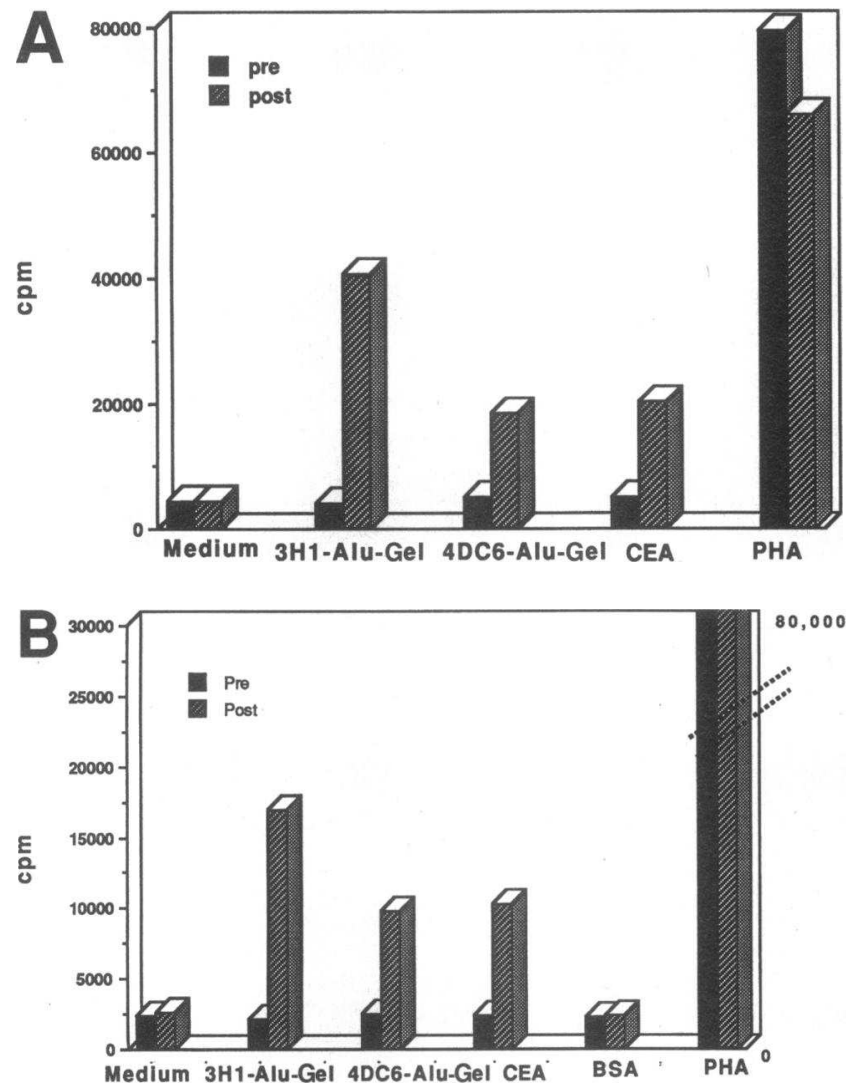

Figure 7. T cell proliferation assay with patients' (No. $1, A$ and No. $12, B$ ) peripheral blood mononuclear cells in the presence of $3 \mathrm{H} 1$-AluGel, iso-allotype matched control 4DC6-Alu-Gel, purified CEA, purified bovine serum albumin (BSA), and phytohemagglutinin. Peripheral blood mononuclear cells were isolated from blood obtained after four immunizations and cultured with $100 \mathrm{ng}$ of different antigens and $2 \mu \mathrm{g}$ of phytohemagglutinin as described in Methods. $\left[{ }^{3} \mathrm{H}\right]$ Thymidine incorporation was measured in pre-(solid bars) and post-therapy (hatched bars) samples. Data are expressed as mean cpm of triplicate wells. The S.D. of the data was $<10 \%$ for each determination.

routine assay. The serial monitoring of CEA correlated with disease progression and all patients who clinically progressed had a rise in their serum CEA levels except patients 5 and 10 who did not secrete CEA.

\section{Discussion}

We have demonstrated that nine of twelve patients injected with aluminum hydroxide precipitated anti-idiotype antibody $3 \mathrm{H} 1$ generated anti-CEA antibody by direct binding to radiolabeled purified CEA. None of these patients had pre-existing antibody to CEA. We also demonstrated binding to autologous and allogeneic tumor as well as immunoprecipitation of purified CEA in selected patients. While the three patients who did not generate a humoral immune response may have been truly anergic, it is possible that the two who had elevated CEA levels (patients 4 and 8) generated small quantities of antibody that was bound to circulating CEA as immune complexes. Indeed, many patients had increasing levels of circulating immune complexes as determined by routine Raji cell assay (data not shown). Also, there is the possibility that some of the circulating anti-CEA antibodies may have bound to patients' tumor cells or were of low affinity. However, five of the patients still showed high binding of antibody to radiolabeled CEA, while four others showed modest binding. In future studies, we will also stimulate patients' peripheral blood mononuclear cells in vitro with CEA or Ab2 for the induction of tumor-specific antibody (36).

Seven patients demonstrated idiotype specific $\mathrm{T}$ cell proliferative responses of primarily $\mathrm{CD} 4 \mathrm{~T}$ cells. Four of them also demonstrated CEA-specific $\mathrm{T}$ cell proliferation in vitro. We will also study these patients' sera for in vitro killing of cultured tumor cells by antibody-dependent cell-mediated cytotoxicity (ADCC) and complement mediated cytotoxicity (CMC) assays. We do not have fresh or frozen autologous tumor tissues from these patients to test for in vitro cytotoxic $T$ cell (CTL) induction, but will use HLA-Class 1 matched cultured colon tumor cell lines as targets.

To our knowledge, this is the first report in the literature describing the generation of specific and reproducible immunity to CEA. Whether this Ab3 and/or cellular immunity can mediate a potential anti-tumor effect remains to be determined. All of the patients in this study had prior chemotherapy and advanced disease; tumor regression was not noted. Future studies will focus on adjuvant trials where the goal will be elimination of minimal residual disease.

Another approach to generate active immunity to CEA has been the development of a recombinant vaccinia virus expressing the human CEA gene $(37,38)$. This was made possible by the cloning of the CEA gene (39). These investigators have demonstrated anti-CEA immune responses in animals but have not yet reported success in clinical trials. Another novel approach to generate CEA immunity that has not yet entered the clinic, is cDNA immunization by a polynucleotide vaccine (40). Other investigators have generated anti-idiotype antibodies that are the internal images of CEA (19-27); clinical results are not reported.

It was interesting that our 3H1 anti-idiotype antibody was effective in eliciting immune responses despite the absence of a strong adjuvant. Aluminum hydroxide-precipitation, although considered weakly immunogenic, appeared to be quite adequate in eliciting immune responses. Aggregation of soluble idiotypic determinants by aluminum hydroxide precipitation likely helped to increase its antigenicity. Also, our antibody was a foreign protein and was injected as an intact immunoglobulin. The Fc portion of the murine immunoglobulin probably served as a "carrier" to help promote the immune responses. It was of further interest that our anti-idiotype antibody and purified CEA were able to stimulate an in vitro CD4 $\mathrm{T}$ cell proliferative response in treated patients. We believe the response observed in some patients against the purified CEA is based on the recognition of processed idiotypic peptides which have homology to the CEA sequence. In preliminary experiments, we have identified a peptide sequence region of CEA which has homology to a CDR of the light chain of our $3 \mathrm{H} 1$ anti-idiotype vaccine.

A variety of non-CEA anti-idiotype antibodies have been shown to generate active tumor immunity in animal models with both humoral immune responses and delayed hypersensitivity (41-49). Perhaps the first suggestion in man that antiidiotype responses might correlate with clinical responses were in patients treated with a non-CEA Ab1 antibody for colorectal cancer who developed anti-idiotypic antibodies and improved clinically (50). Subsequent clinical trials using polyclonal nonCEA goat anti-idiotype (Ab2) vaccines for colorectal cancer (51), and monoclonal anti-idiotypes for malignant melanoma 
$(52,53)$ have demonstrated that anti-idiotype vaccine therapy leads to active immune responses. In a recent study, idiotypespecific immune responses were induced in patients with $B$ cell lymphoma against the immunoglobulin idiotype expressed by their tumors (54). This latter study differed from ours in that the idiotype immunogen was derived from the patients' tumors, coupled to keyhole limpet hemocyanin and mixed with a potent adjuvant. Therefore, while we used a single anti-idiotype antibody as an antigen surrogate to treat all of our patients, these investigators generated an individualized vaccine for each of their patients.

In summary, we have demonstrated specific active immunity to CEA in patients with advanced colorectal cancer treated with an anti-idiotype antibody that "mimics" CEA. In this Phase $1 \mathrm{~b}$ clinical trial, we could only accrue patients who failed conventional therapy. All of them had widespread advanced disease. The main purpose of this clinical trial was not to assess tumor response, but to determine the host's immunological response to the vaccine therapy. Some primary questions have been resolved. This anti-idiotype antibody can evoke an Ab3 as well as cellular immune response in patients, and any Ab3 so derived, behaves as an $\mathrm{Ab} 1$-like antibody ( $\left.\mathrm{Ab} 1^{\prime}\right)$. The intensity of the $\mathrm{Ab} 3$ response appeared to correlate positively with anti-CEA antibody ( $\left.\mathrm{Abl}^{\prime}\right)$ and $\mathrm{T}$ cell proliferative responses. Immune responses appeared independent of the level of circulating CEA. While there are too few patients to compare the 1 $\mathrm{mg}, 2$ and $4 \mathrm{mg}$ doses; it is clear that patients were able to generate immunity at each of these doses. At the completion of this study we will statistically compare the different dose levels. Toxicity was restricted to local cutaneous reactions lasting 24$48 \mathrm{~h}$ with mild fever and chills and was relieved by acetaminophen.

Collectively, the immune responses in patients treated with an idiotype vaccine, which induced humoral and cellular responses against an otherwise non-immunogenic tumor antigen, justify follow-up clinical studies in patients with minimal tumor burden, as well as basic immunobiological studies to understand the mechanisms of the $\mathrm{T}$ cell response at the clonal level. Such studies may lead to the development of second generation idiotype vaccines consisting of cytokine-antibody fusion proteins (55) and of idiotype derived peptide vaccines (56).

\section{Acknowledgments}

This work was supported by National Institutes of Health grant P01CA 57165.

\section{References}

1. Gold, P., and S. O. Freedman. 1965. Demonstration of tumor specific antigens in human colonic carcinomata by immunological tolerance and absorption techniques. J. Exp. Med. 121:439-462.

2. Primus, F. J., K. D. Newell, A. Blue, and D. M. Goldenberg. 1983. Immunological heterogeneity of carcinoembryonic antigen distinguished by monoclonal antibodies. Cancer Res. 43:686-92.

3. Hansen, H. J., D. M. Goldenberg, E. S. Newman, R. Grebenau, and R. M. Sharkey. 1993. Characterization of second-generation monoclonal antibodies against carcinoembryonic antigen. Cancer. 71:3478-85.

4. Kuroki, M., F. Arakawa, M. Haruno, M. Murakami, M. Wakisaka, H. Higuchi, S. Oikawa, H. Nakazato, and Y. Matsuoka. 1992. Biochemical characterization of 25 distinct carcinoembryonic antigen (CEA) epitopes recognized by 57 monoclonal antibodies and categorized into seven groups in terms of domain structure of the CEA molecule. Hybirdoma. 11:391-407.

5. Goldenberg, D. M. 1993. Monoclonal antibodies in cancer detection and therapy. 1993. Am. J. Med. 94:297-312.
6. Pressman, D., C. T. Ming, and A. L. Grossberg. 1979. Carcinoembryonic antigen-binding immunoglobulin isolated from normal human serum by affinity chromatography. JNCI (J. Natl. Cancer Institue). 62:1367-1371.

7. Kapsopoulou-Dominos, K., and F. A. Anderer. 1979. Circulating carcinoembryonic antigen immune complexes in sera of patients with carcinomata of the gastrointestinal tract. Clin. Exp. Immunol. 35:190-195.

8. Kapsopoulou-Dominos, K., and F. A. Anderer. 1979. An approach to the routine estimation of circulating carcinoembryonic antigen immune complexes in patients with carcinomata of the gastrointestinal tract. Clin. Exp. Immunol. 37:2532.

9. Lejtenyi, C. M., S. O. Freedman, and P. Gold. 1971. Response of lymphocytes from patients with gastrointestinal cancer to the carcinoembryonic antigen of the human digestive system. Cancer. 28:115.

10. Orefice, S., G. Fossati, E. Pietrojusti, and G. Bonfanti. 1982. Delayed cutaneous hypersensitivity reaction to carcinoembryonic antigen in cancer patients. Tumori. 68:473-475.

11. Lindenmann, J. 1973. Speculations on Ids and homobodies. Ann. Immunol. (Paris). 124:171-184.

12. Jerne, N. K. 1974. Towards a network theory of the immune system. Ann. Immunol. (Paris). 125C:373-389.

13. Paxton, R. J., G. Mooser, H. Pande, T. D. Lee, and J. E. Shivley. 1987 Sequence analysis of carcinoembryonic antigen: Identification of glycosylation sites and hormology with the immunoglobulin super-gene family. Proc. Natl. Acad. Sci. USA. 84:920-924.

14. Thompson, J., and W. Zimmerman. 1988. The carcinoembryonic antigen gene family: structure, expression, and evolution. Tumour Biol. 9:63-83.

15. Benchimol, S., A. Fuks, S. Jothy, N. Beauchemia, K. Shirota, and C. Stanners. 1989. Carcinoembryonic antigen, a human tumor marker functions as an intercellular adhesion molecule. Cell. 57:327-334.

16. Oikawa, S., C. Inuzuka, M. Kuroki, Y. Matsuoka, G. Kosaki, and H. Nakazato. 1989. Cell adhesion activity of non-specific cross-reacting antigen (NCA) and carcinoembryonic antigen (CEA) expressed on CHO cell surface: homophilic and heterophilic adhesion. Biochem. Biophys. Res. Commun. 164:3945.

17. Cazenave, P. A. 1977. Idiotypic-anti-idiotypic regulation of antibody synthesis in rabbits. Proc. Natl. Acad. Sci. USA. 74:5122-5125.

18. Bona, C., E. Herber-Katz, and W. E. Paul. 1981. Idiotype-anti-idiotype regulation. I. Immunization with a levan-binding myeloma protein leads to the appearance of auto-anti-(anti-idiotype) antibodies and to the activation of silent clones. J. Exp. Med. 153:951-967.

19. Tsujisaki, M., K. Imai, S. Tokuchi, Y. Hanzawa, T. Ishida, H. Kitagawa, Y. Hinoda, and A. Yachi. 1991. Induction of antigen-specific immune response with use of anti-idiotypic monoclonal antibodies to anti-carcinoembryonic antigen antibodies. Cancer Res. 51:2599-2604.

20. Tsujisaki, M., Y. Hinoda, S. Tokuchi, Y. Hanzawa, Y. Arimura, J. Masuya, H. Kitagawa, E. Okochi, T. Shimamura, J. Hamuro, K. Imai, and A. Yachi. 1993. The analysis of internal image-bearing anti-idiotypic monoclonal antibody in relation to carcinoembryonic antigen. J. Immunol. 150:508-516.

21. Durrant, L. G., G. W. L. Denton, E. Jacobs, M. Mee, R. Moss, E. B. Austin, R. W. Baldwin, J. D. Hardcastle, and R. A. Robins. 1992. An idiotypic replica of carcinoembryonic antigen inducing cellular and humoral responses directed against human colorectal tumors. Int. J. Cancer. 50:811-816.

22. Gaida, F-J, U. Fenger, C. Wagener, and M. Neumaier. 1992. A monoclonal anti-idiotypic antibody bearing the image of an epitope specific to the human carcinoembryonic antigen. Int. J. Cancer. 51:459-465.

23. de Moraes, J. Z., C. R. W. Carneiro, F. Buchegger, J.-P. Mach, and J. D. Lopes. 1992. Induction of an immune response through the idiotypic network with monoclonal anti-idiotype antibodies in the carcinoembryonic antigen system. J. Cell. Biochem. 50:324-335.

24. Austin, E. B., R. A. Robins, R. W. Baldwin, and L. G. Durrant. 1991 Introduction of delayed hypersensitivity to human tumor cells with a human monoclonal anti-idiotypic antibody. J. Natl. Cancer Inst. 83:1245-1248.

25. Losman, M. J., K. E. Novick, D. M. Goldenberg, and M. Monestier. 1994. Mimicry of a carcinoembryonic antigen epitope by a rat monoclonal anti-idiotype antibody. Int. J. Cancer. 56:580-584.

26. Irvine, K., and J. Schlom. 1993. Induction of delayed-type hypersensitivity responses by monoclonal anti-idiotypic antibodies to tumor cells expressing carcinoembryonic antigen and tumor-associated glycoprotein-72. Cancer Immunol. Immunother. 36:281-292.

27. Losman, M. J., M. Monestier, H. J. Hansen, and D. M. Goldenberg. 1990. Baboon anti-idiotype antibodies mimic a carcinoembryonic antigen epitope. Int. J. Cancer. 46:310-314.

28. Koprowski H., Z. Steplewski, K. Mitchell, M. Herlyn, D. Herlyn, and P. Fuhrer. 1979. Colorectal carcinoma antigens detected by hybridoma antibodies. Somat. Cell Genet. 5:957.

29. Bhattacharya-Chatterjee, M., S. Mukerjee, W. Biddle, K. A. Foon, and H. Köhler. 1990. Murine monoclonal anti-idiotype antibody as a potential network antigen for human carcinoembryonic antigen. J. Immunol. 145:2758-2765.

30. Chakraborty, M., K. A. Foon, H. Köhler, and M. Bhattcharya-Chatterjee. 1994. Murine monoclonal anti-idiotype antibody induces a specific antibody re- 
sponse to human carcinoembryonic antigen (CEA) in cynomolgus monkeys. $F A$ SEB (Fed. Am. Soc. Exp. Biol.) J. A504.

31. Bhattacharya-Chatterjee, M., M. W. Pride, B. K. Seon, and H. Köhler. 1987. Idiotype vaccines against human T-cell acute lymphoblastic leukemia (TALL). I. Generation and characterizations of biologically active monoclonal anti-idiotypes. J. Immunol. 5:562-573.

32. Bhattacharya-Chatterjee, M., S. K. Chatterjee, S. Vasile, B. K. Seon, and H. Köhler. 1988. Idiotype vaccines against T-cell leukemia. II. Generation and characterization of monoclonal idiotype cascade (Ab1, Ab2 and Ab3). J. Immunol. 141:1398-1403.

33. Khazaeli, M. B., M. N. Saleh, R. H. Wheeler, W. J. Huster, H. Holden, R. Carrano, and A. F. LoBuglio. 1988. Phase I trial of multiple large doses of murine monoclonal antibody CO17-1A. II. Pharmacokinetics and immune response. J. Natl. Cancer Inst. 80:937-942.

34. Laemmli, U.K. 1970. Cleavage of structural proteins during the assembly of the head of leactoriophage T4. Nature (Lond.). 227:680-685.

35. Hansen, H. J., G. LaFontaine, E. S. Newman, M. K. Schwartz, A. Malkin, K. Mojzisik, E. W. Martin, and D. M. Goldenberg. 1989. Solving the problem of antibody interference in commercial "sandwich"-type immunoassays of carcinoembryonic antigen. Clin. Chem. 35(1):146-151.

36. DeFreifas, Er., H. Suzuki, D. Herlyn, M. Lubeck, H. Sears, M. Herlyn, and $\mathrm{H}$. Koprowski. 1985. Human antibody induction to the idiotypic and antiidiotypic determinants of a monoclonal antibody against gastrointestinal carcinoma antigens. Curr. Top. Microbiol. Immunol. 119:75-88.

37. Kantor, J., K. Irvin, S. Abram, H. Kaufman, J. DiPietro, and J. Schlom. 1992. Antitumor activity and immune responses induced by a recombinant carcinoembryonic antigen-vaccinia virus vaccine. J. Natl. Cancer Inst. 84:1084-1091.

38. Kantor, J., K. Irvine, S. Abrams, P. Snoy, R. Olsen, J. Greiner, H. Kaufman, D. Eggensperger, and J. Schlom. 1992. Immunogenicity and safety of a recombinant vaccinia virus vaccine expressing the carcinoembryonic antigen gene in a non-human primate. Cancer Res. 52:6917-6925.

39. Robbins, F. F., J. A. Kantor, M. Salgaller, P. H. Hand, P. D. Fernsten, and J. Schlom. 1991. Transduction and expression of the human CEA gene in murine colon carcinoma cell line. Cancer Res. 51:3652-3662.

40. Conroy, R. M., A. F. LoBuglio, J. Kantor, J. Schlom, F. Loechel, S. E Moore, L. A. Sumerel, D. L. Barlow, S. Abrams, and D. T. Curiel. 1994. Immune response to a carcinoembryonic antigen polynucleotide vaccine. Cancer Res. 54:1164-1168.

41. Dunn, P. L., C. A. Johnson, J. M. Styles, S. S. Pease, and C. J. Dean 1987. Vaccination with syngeneic monoclonal anti-idiotype protects against a tumor challenge. Immunol. 60:181-186.

42. Lee, V. K., T. G. Harriott, V. K. Kuchroo, W. J. Halliday, I. Hellstrom, and K. E. Hellstrom. 1985. Monoclonal anti-idiotope antibodies related to a murine oncofetal bladder tumor antigen induce specific cell-mediated tumor immunity. Proc. Natl. Acad. Sci. USA. 82:6286-6290.

43. Binz, H., B. Meier, and H. Wigzell. 1982. Induction or elimination of tumor-specific immunity against a chemically induced rat tumor using auto-antiidiotypic antibodies. Int. J. Cancer. 29:417-423.
44. Kennedy, R. C., G. R. Dreesman, J. S. Butel, and R. E. Landford. 1985. Suppression of in vivo tumor formation induced by simian virus 40-transformed cells in mice receiving anti-idiotypic antibodies. J. Exp. Med. 162:1432-1449.

45. Forstrom, J. W., K. A. Nelson, G. T. Nepom, I. Hellstrom, and K. E. Hellstrom. 1983. Immunization to a syngeneic sarcomas by a monoclonal autoanti-idiotypic antibody. Nature (Lond.). 303:627-629.

46. Nelson, K. A., E. George, C. Swenson, J. W. Forstrom, and K. E. Hellstrom. 1987. Immunotherapy of murine sarcomas with auto-anti-idiotypic monoclonal antibodies which bind to tumor-specific T cells. J. Immunol. 139:21102117.

47. Kaminski, M. S., K. Kitamura, D. G. Maloney, and R. Levy. 1987. Idiotype vaccination against murine B cell lymphoma. Inhibition of tumor immunity by free idiotype protein. J. Immunol. 138:1289-1296.

48. Raychaudhuri, S., Y. Saeki, J. J. Chen, H. Iribe, H. Fuji, and H. Köhler. 1987. Tumor- specific idiotype vaccines. II. Analysis of the tumor-related network response induced by the tumor and by internal image antigens $(\mathrm{Ab} 2 \beta) . J . I m m u-$ nol. 139:271-278.

49. Raychaudhuri, S., Y. Saeki, J. J. Chen, H. Iribe, H. Fuji, and H. Köhler. 1987. Tumor- specific idiotype vaccines. III. Induction of $\mathrm{T}$ helper cells by antiidiotype and tumor cells. J. Immunol. 139:2096-2102.

50. Koprowski, H., D. Herlyn, M. Lubeck, E. Defreitas, and H. F. Sears. 1984. Human anti- idiotype antibodies in cancer patients: is the modulation of the immune response beneficial for the patient? Proc. Natl. Acad. Sci. USA. 81:216-219.

51. Heryln, D., M. Wettendorff, E. Schmoll, D. Iliopoulos, I. Schedel, U. Dreikhausen, R. Raab, A. H. Ross, H. Jaksche, M. Scriba and H. Koprowski. 1987. Anti-idiotype immunization of cancer patients: Modulation of the immune response. Proc. Natl. Acad. Sci. USA. 84:8055-8059.

52. Mittleman, A., et al. 1990. Active specific immunotherapy in patients with melanoma. A clinical trial with mouse anti-idiotypic monoclonal antibodies elicited with syngeneic anti-high-molecular-weight-melanoma-associated antigen monoclonal antibodies. J. Clin. Invest. 86:2136-2144.

53. Mittleman, A., et al. 1992. Human high molecular weight melanomaassociated antigen (HMW-MAA) mimicry by mouse anti-idiotypic monoclonal antibody MK2-23: induction of humoral anti-HMW-MAA immunity and prolongation of survival in patients with stage IV melanoma. Proc. Natl. Acad. Sci. USA. 89:466-470.

54. Kwak, L., M. Campbell, B. Czerwinski, S. Hart, R. Miller, and R. Levy. 1992. Induction of immune responses in patients with B cell lymphoma against the surface-immunoglobulin idiotype expressed by their tumors. N. Engl. J. Med. 327:1209-1215.

55. Tao, M-H., and R. Levy. 1993. Idiotype/granulocyte-macrophage colonystimulating factor fusion protein as a vaccine for B-cell lymphoma. Nature (Lond.). 362:755-758.

56. Williams, W. W., S. D. London, D. B. Weiner, S. Wadsworth, J. A. Berzofsky, F. Robey, D. H. Rubing, and M. I Greene. 1989. Immune response to a molecularly defined internal image idiotype. J. Immunol. 142:4392-4400. 